Chapter 3

\title{
BOD Biosensors: Application of Novel Technologies and Prospects for the Development
}

\author{
A. Reshetilov, V. Arlyapov, V. Alferov and \\ T. Reshetilova \\ Additional information is available at the end of the chapter \\ http://dx.doi.org/10.5772/52385
}

\section{Introduction}

Household and industrial human activities cause ever increasing pollution of water bodies of rivers, lakes, water reservoirs, seas. Express assessment of the extent of pollution by organic compounds is an important and, in some cases, essential component of ecological control. Given the constantly growing list of substances released into the environment as pollutants, it can be stated that complete chemical analysis is a complex and expensive procedure. An efficient tool of analysis proves to be methods based on an integral assessment of organic components. In this context, significant attention is given to the development of biosensor methods of control that enable an integral estimate of pollution density, considerably increase operational efficiency of the analysis and reduce its cost (D'Souza, 2001).

An essential integral characteristic of the quality of water is biochemical oxygen demand (BOD), i.e., the amount of dissolved oxygen (in $\mathrm{mg}$ ) required to oxidize all biodegradable organic compounds that occur in $\left(1 \mathrm{dm}^{3}\right.$ of $)$ water. The BOD assessment is an empirical test in which a standardized laboratory procedure is used to determine the oxygen demand in analyzed water samples. The BOD is determined conditionally by the change of oxygen content before and after placing a water sample into a sealed flask and holding it for a certain period of time. The standard BOD determination method assumes incubation of an oxygensaturated sample, into which activated sludge (a mixture of various microorganisms) is introduced, for $5,7,10$ or 20 days $\left(\mathrm{BOD}_{5}, \mathrm{BOD}_{7}, \mathrm{BOD}_{10}\right.$ or $\mathrm{BOD}_{20}$, respectively) at $20^{\circ} \mathrm{C}$ (Standard Methods..., 1992). The obtained result - the amount of consumed oxygen normalized to $1 \mathrm{dm}^{3}$ - characterizes the total content of biochemically oxidizable organic impurities in water, as well as its capability of self-clarification. In surface waters of most water bodies, the values of $\mathrm{BOD}_{5}$ usually change within the range of $0.5-4 \mathrm{mg} / \mathrm{dm}^{3}$ and are subject 
to seasonal and diurnal variations. Changes of $\mathrm{BOD}_{5}$ values vary rather significantly depending on the extent of water body pollution. Depending on the category of a water body, the value of $\mathrm{BOD}_{5}$ is regulated as follows: it should be no more than $3 \mathrm{mg} / \mathrm{dm}^{3}$ for water bodies of household water use and no more than $6 \mathrm{mg} / \mathrm{dm}^{3}$ for water bodies of social-amenity and recreational water use. For seas (categories I and II of fish-husbandry water utilization) the $\mathrm{BOD}_{5}$ at $20^{\circ} \mathrm{C}$ should not exceed $2 \mathrm{mg} / \mathrm{dm}^{3}$. The BOD test is also widely used at wastewater treatment facilities to assess the biodegradation efficiency in wastewater purification processes. The traditional BOD test has certain advantages, is a universal means of assaying most samples of waste waters and water bodies; besides, it requires no expensive equipment. However, the test has serious limitations with respect to analysis time. This traditional technique is largely devalued by its low responsiveness. It can provoke ecologically hazardous situations, when the inflow of accidentally polluted waters to the treatment facilities or their incomplete purification in the regeneration process goes unnoticed.

Operational analysis is made possible by developing BOD assessment methods based on the use of biosensor analyzers. The biosensor is an integrated device capable of providing quantitative and semi-quantitative analytical information using a biological recognition element that is in close contact with the transducer. BOD biosensor R\&D has been underway since 1970s (Karube et al., 1997b; Hikuma et al., 1979), and these systems continue to be actively developed at present (Rodriguez-Mozaz et al., 2006). It should be noted that biosensors enable a rapid determination of the $\mathrm{BOD}$ index $\left(\mathrm{BOD}_{\mathrm{bs}}\right)$. However, $\mathrm{BOD}_{\mathrm{bs}}$ is not always identical to the value of the traditional $\mathrm{BOD}_{5}$. There is a simple explanation of this effect. The receptor element of the biosensor may contain one or several cultures. The culture(s) may have a rather broad substrate specificity, which will undoubtedly be less broad than in the cultures of activated sludge used in the standard $\mathrm{BOD}_{5}$ method. Therefore, the oxidation of organic compounds by the culture(s) occurring in the receptor element will always be lower than by activated sludge cultures.

Recently, novel approaches to the biosensor analysis of the BOD have started to be developed; these approaches make it possible to achieve an acceptable fit of the data obtained by biosensor measurements with those determined by traditional methods and to approach the solution of many applied issues. Thus, methods of determining the BOD in water bodies of rivers are being developed, which is of extreme importance along with the assessment of the BOD in waste waters (Chee, 2011). A highly efficient approach is to couple two procedures - cleanup of polluted wastewaters from organic impurities and production of electric energy by using biofuel cells based on microbial cells (Deng et al., 2012; Du et al., 2007). Herewith, it should be noted that the general tendency of the search is to increase the correlation between the data measured by the biosensor and those determined by traditional methods. The correlation of the data obtained using a biosensor analyzer with those by the $\mathrm{BOD}_{5}$ method can be of the order of $0.95-0.98$ (Bourgeois et al., 2001). Calibration of the biosensor for BOD measurements is made using synthetic waste waters, or the biorecognition element of the BOD biosensor is made based on microorganisms capable of efficient oxidation of particular waste waters. Thus, it is expedient to develop biosensors, choose microorganisms and calibration solutions that would provide for the most 
efficient detection of the BOD in accordance with the particular type of waste waters, i.e., to develop specialized BOD biosensors.

The popularity of and demand for R\&D of BOD-determination biosensor systems logically resulted in commercialization and industrial production of a number of models. Nevertheless, BOD-biosensor systems still have a number of limitations that impede their use. These include drawbacks in the standardization procedure, imperfections of legislation in most countries, complicated service requirements and insufficient stability of used microbial cultures with respect to heavy metals and various toxic substances (Rodriguez-Mozaz et al., 2006).

Reviews on microbial sensors (D'Souza, 2001; Liu \& Mattiasson, 2002; Lei et al., 2006; Xu \& Ying, 2011; Ponomareva et al., 2011), as well on the use of biosensors for analyzing objects of the environment and for ecological monitoring (Rodriguez-Mozaz et al., 2006; Baeumner, 2003) give examples of BOD sensors developed. An important role of biorecognition elements based on eukaryotic microorganisms in biosensors for solving environmental problems is noted, including for determining the BOD of water bodies (Walmsley\& Keenan, 2000). Detailed information on BOD sensors based on Clark-type electrode is summed up, as well as on some commercially available biosensor systems developed prior to 2000 (Liu \& Mattiasson, 2002).

In this review, we generalize information about the principles of functioning, design, analytical characteristics of BOD biosensors, the properties of biorecognition elements; the functioning parameters and characteristics of various BOD sensor types are given.

\section{Operating principles of BOD biosensors}

\subsection{Oxygen electrode-based film biosensors}

Most BOD sensors described are film-type microbial sensors based on whole cells. The principle of their operation is based on the measurement of oxygen consumption by microorganisms immobilized on the surface of the transducer. In 1977, Karube et al. (1977b) published a paper, which first described a microbial sensor for $\mathrm{BOD}_{\mathrm{bs}}$ determination using microorganisms taken from activated sludge of wastewater treatment facilities. A feature of such biosensors is that between the porous (most often, cellulose) membrane and the gas permeable membrane of the oxygen electrode there is a layer of microbial film that forms the biological recognition element. Part of oxygen occurring in the layer of immobilized microorganisms is consumed in oxidation of organic compounds contained in the sample. Remaining oxygen penetrates through the gas permeable teflon membrane and is reduced at the cathode of the oxygen electrode. The strength of current in the system is directly proportional to the magnitude of oxygen reduced at the electrode. After an equilibrium is established between the diffusion of oxygen to the layer of immobilized microorganisms and the endogenous respiration rate of immobilized microorganisms, the equilibrium (background) current is recorded. When a waste water sample is introduced into a measuring cuvette, organic substances of the analyzed sample are utilized by immobilized microorganisms, as the result of which the respiratory rate of the cells increases to lead to an increase of the oxygen consumption 
rate. In this case, a smaller amount of oxygen penetrates through the teflon membrane to be reduced. The current will decrease until a new equilibrium is established. When the buffer solution for washing the biosensor is fed to the measuring cuvette, the microbial endogenous respiratory rate is restored and the initial equilibrium of the oxygen flows in the system is re-established. As the process is controlled by the rate of substrate diffusion to the layer of immobilized cells, the sensor signal will be proportional to the concentration of readily oxidized substrates in the sample.

Two methods of biosensor-response processing are used to obtain the analytical signal: the equilibrium method (determination by the endpoint) and the kinetic method (determination by the initial rate) (Tan et al., 1993). In the equilibrium method, the $\mathrm{BOD}_{\mathrm{bs}}$ is determined using the difference between currents in two equilibrium states of the biosensor before and after substrate is introduced. The measurement time in this case is from 15 to $30 \mathrm{~min}$ with the subsequent rather long recovery, which can take $1 \mathrm{~h}$ and more. In the kinetic method, the dependence of the rate of current strength (the first derivative of current with respect to time) on time is used as a sensor response. This rate is registered after a sample is added. This parameter reflects the rate of microbial respiration and, to a certain extent, is proportional to the concentration of substrate. In this case, the sensor response is registered within 15 to $30 \mathrm{~s}$, and the recovery time of the biorecognition element is less than $10 \mathrm{~min}$. It should be noted that a broader range of determined BOD values can be achieved by taking the initial rate of response as the biosensor response, at an insignificant loss in reproducibility (Yang et al., 1997). Thus, the kinetic method of biosensor signal processing is more preferable in the case when the BOD index should be constantly controlled, e.g., in the course of the purification of waste waters or in the analysis of a large number of samples (Liu et al. 2000).

At present, novel biofilm BOD sensors based on the oxygen electrode are developed (Rodriguez-Mozaz et al., 2006; Bourgeois et al., 2001; Liu \& Mattiasson, 2002; Baeumner, 2003). Major attention is given to the improvement of BOD sensor parameters: increase of stability, rise of correlation of the data obtained by the biosensor and standard $\mathrm{BOD}_{5}$ assessment methods. First and foremost, this is associated with the search for new efficient microorganisms, use of modern materials and new biomaterial immobilization methods.

\subsection{Oxygen electrode-based bioreactor-type biosensor systems}

The $\mathrm{BOD}_{\mathrm{bs}}$ is determined using bioreactor-type sensor systems with the respirometer to constantly measure the respiratory activity of microbial suspension. Strictly speaking, in accordance with the IUPAC definition, such systems are not biosensors, because the biorecognition element is not in direct contact with the transducer. However, such systems have found wide use at wastewater treatment facilities for continuous control of the extent of purification (Iranpour \& Zermeno, 2008). A common feature of all respirometric BOD sensors is the presence of bioreactors, in which activated sludge (or individual microorganisms) and readily oxidized organic substances are together (Spanjers et al., 1996). Samples of waste waters are constantly transported through the flow reactor, which has a small volume (Spanjers et al., 1991, 1993). Most often, unidentified microorganisms from waste water, e.g., activated 
sludge, are used in such systems as a biorecognition element. To increase the reproducibility of the results, it is proposed to use individual strains of microorganisms with a broad range of oxidized substrates that belong to the genera Trichosporon (Sohn et al., 1995), Rhodococcus and Issatchenkia (Heim et al., 1999).

An advantage of the bioreactor configuration of the recognition elements is that the transducer in such systems is easily replaceable. This does not disturb the activity of microorganisms. Besides, the bioreactor-type BOD sensor has more stable operational characteristics as compared with the biofilm type (Praet et al., 1995). A drawback of these devices is their stationary arrangement and impossibility of field measurements. Thus, reactor-type biosensor systems have a strictly definite purpose: continuous control of waste water purification processes at respective facilities.

\subsection{Mediator-type biosensors}

The BOD value determined using microbial respiration can be affected by the amount of dissolved oxygen in the sample. It is known that some synthetic compounds (artificial electron acceptors) can be reduced by certain microorganisms, i.e., are artificial acceptors of electrons (Tkac et al., 2003). If these compounds possess reversible redox properties, they can serve as carriers of electrons from the biocatalytic systems of microorganisms to the electrode.

When using mediators, the results of measurements become in practice independent of the partial pressure of oxygen in the medium, and, if the oxidation of the reduced mediator does not involve protons, the mediator electrode can be relatively insensitive to $\mathrm{pH}$ changes. Thus, one of the most promising trends is the development of BOD biosensors using electron transport mediators (Liu \& Mattiasson, 2002; Tkac et al., 2003; Yoshida et al., 2000; Trosok et al., 2001; Yoshida et al., 2001; Nakamura et al., 2007a,b; Chen et al., 2008; Liua et al., 2010). The equilibrium state of current in such systems sets in in several seconds, which provides for a higher speed of analysis. Due to the large area of the measuring electrode, appreciable currents that can be greater than currents of the oxygen electrode are generated in mediator microbial sensors (Arlyapov et al., 2008a). An essential characteristic of biosensors is the possibility of their miniaturization. Using screenprinted electrodes, it is possible to develop cheap disposable biosensors based on microbial whole cells to extend the potential of their use by a broad range of consumers (Farré \& Barceló, 2001).

One more advantage of using mediators is that the BOD can be measured under anaerobic conditions, because the microbial respiratory chain enzymes are capable of regeneration owing to the reduction of artificial electron acceptors. Pasco and co-workers (2004) proposed a fast microbial technology of BOD measurements under anaerobic conditions in the presence of co-substrate potassium hexacyanoferrate(III). Addition of substrate to the measuring cuvette increases the catabolic activity of microorganisms and leads to the accumulation of the reduced form of mediator, which is successfully re-oxidized at the working electrode; the amount of electricity is measured by a coulometric transducer. 


\subsection{Microbial biofuel cells as BOD sensors}

Carube and coworkers (1977a) developed a sensor based on the biofuel cell (BFC)for the determination of the $\mathrm{BOD}_{\mathrm{bs}}$. The current generated in the biofueld cell is the result of the biooxidation of hydrogen or is due to the formation of products from organic compounds by way of reduction under the action of the bacteria Clostridium butyricum under anaerobic conditions. A significant contribution to the development of BOD sensors based on mediator-free biofuel cells was made by Korean investigators (Kim et al., 2003a, b; Moon et al., 2004; Chang et al., 2004, 2005). The long-time stability of a system based on a mediator-free fuel cell was an enormous achievement in the development of BOD sensors: the sensor was operated for 5 years without any maintenance (Moon et al., 2004). At the same time, a slow response time (about $1 \mathrm{~h}$ ) and the fixed position of the system restricts its applications.

\subsection{Optical BOD biosensors}

Intensive development of fibre-optic devices at the end of the last century made it possible to produce miniature optical biosensors (Hyun et al., 1993; Karube \& Yokoyama, 1993; Chee et al., 2000; Sakaguchi et al., 2003; Kwok et al., 2005; Lin et al., 2006; Jiang et al., 2006; Pang et al., 2007; Sakaguchi et al., 2007). There are two approaches to the development of optical BOD sensors: to use luminescent bacteria in the biorecognition element of the sensor or to use a luminescent support for biomaterial. In the former case, the measurement principle is based on the relation between the intensity of luminescence produced by bacteria and the cell assimilation of organic compounds from waste water samples (Hyun et al., 1993; Karube \& Yokoyama, 1993; Sakaguchi et al., 2003; Sakaguchi et al., 2007). In the former case, oxygensensitive dyes are introduced into the material of the support, and whole microbial cells are used in this matrix as a biorecognition element. Microbial respiration intensity depends on the content of organic compounds in the analyzed sample, which are oxidized by microorganisms in the presence of oxygen. A change in the content of oxygen in the film is registered by optical methods using a dye (Chee et al., 2000; Sakaguchi et al., 2003; Kwok et al., 2005; Lin et al., 2006; Jiang et al., 2006; Pang et al., 2007). Optical biosensors possess a high sensitivity and, thus, make it possible to determine low BOD values. An important advantage of such systems is that they enable micro printed circuit boards, microsensors, on-chip biosensors (Sakaguchi et al., 2003; Sakaguchi et al., 2007).

\subsection{Other types of BOD biosensors}

BOD determination methods using biosensors are not limited by those described above. Thus, for instance, Vaiopoulou and co-workers (2005) developed a biosensor for on-line determination of the BOD in wastewater treatment facilities. The main operating principle of the biosensor is based on the on-line measurement of the concentration of $\mathrm{CO}_{2}$ produced in the degradation of waste waters' carbon component by microorganisms.

An unconventional approach to BOD determination is described by Tønning et al. (2005). Samples of waste water from the a Swedish cellulose company at various degrees of purification and pure water were analyzed using an amperometric biosensor with several cells 
and electrodes using mathematical methods of chemometry for processing the array of obtained data (the so called biosensor language). Waste water samples were characterized by the chemical consumption of oxygen, biological consumption of oxygen, total amount of organic carbon, suppression of nitrification, inhibition of respiration and toxicity with respect to Vibrio fischeri, freshwater marine alga Pseudokirchneriella subcapita and freshwater crustacean Daphnia magna.

Another approach to BOD detection is based on the registration of temperature changes caused by microbial destruction of organic compounds. This approach is based on the use of calorimetric transducers: a biosensor based on this transducer is described in Mattiasson et al. (1977). In recent years, this trend has not been intensively developed.

\section{Biorecognition elements of BOD sensors}

\subsection{Microorganisms as the basis of biorecognition}

To develop biorecognition elements of BOD sensors, use is made of either pure cultures with certain consumer properties (a broad range of oxidized substrates, resistance to negative environmental factors or specificity with respect to certain waste waters), or a mixture of identified microorganisms (artificial associations), or induced consortium of microorganisms, or else activated sludge and even thermally killed bacteria. Each of these approaches has its advantages and disadvantages.

Usually BOD biosensors based on a pure culture have an advantage of biosensor system stability. At the same time, these biosensors may show a decreased value of the BOD due to the limited range of substrates oxidized by one strain. Whole cells of bacteria (Bacillus polymyxa, Bacillus subtilis, Pseudomonas putida) or yeasts (Arxula adeninivorans, Hansenula anomala, Klebsiella, Candida, Trichosporon,Serratia marcescens, Saccharomyces cerevisiae) are known to be used as biocatalysts. The yeasts are a more preferable biomaterial for almost all types of biosensors, as they are resistant to negative environmental factors and can function in biosensor's recognition element for a long time (Seo et al., 2009; Dhall et al., 2008). At the same time, yeast cultures are more liable to contamination than bacterial cultures.

The number of oxidized substrates is increased by using microbial associations, consisting more often of two strains, e.g., Trichosporon cutaneum and Bacillus licheniformis (Suriyawattanakulet al., 2002). As most of the described BOD sensors developed with the view to improve the convergence and operational stability, this biorecognition element makes use of a mixture of two identified strains. This led to expand the substrate specificity and to stabilize the sensor operation for a long period of time. BOD sensors based on a composite microbial population, such as in activated sludge or microbial consortia, have a high ability to detect a broad range of substrates. However, due to the instability of the composition in the consortium the sensor operation often becomes unstable in the course of time.

Biosensors based on living cells require their vital activities to be constantly sustained and need nutrients and minerals in long-time storage. BOD sensors based on thermally killed 
cells do not have this drawback. Cells killed by temperature can be stored in phosphate buffer for a long time at room temperature (Tan \& Lim, 2005; Qian \& Tan, 1999; Tag et al., 2000).

\subsection{Immobilization of microorganisms}

The method of immobilizing microorganisms is for each biosensor an important determining procedure, as, in fact, it sets the basic parameters of BOD biosensors. Immobilization determines their lifetime, operational stability, response, sensitivity. In this context, we should note continued studies on the introduction of new modifications of immobilization techniques (Guo et al., 2008). Microbial cells on the surface of the physico-chemical transducer are retained in most cases by simple adsorption, i.e., cells are placed, for the most part, on a porous membrane by suction or retention of water by hydrogels, a polyvinyl alcohol aqueous solution (Qian \& Tan, 1999 ) or polycarbomoyl sulphonate (Tag et al., 2000; Chan et al., 2000). For BOD sensor miniaturization, the method of crosslinking rubber (ENT-3400) under the action of UV light was used to immobilize cells on the surface of a micro-oxygen electrode (Lehmann et al., 1999). As an alternative, disposable BOD sensors can be used, in which the biofilm should be readily replaceable. A BOD sensor was developed whose biorecognition element was prepared by mixing magnetic powder with activated sludge. Magnetized sludge was then placed on the teflon membrane of the cathode and retained due to magnetic interactions (Yang et al., 1996).

A promising modern trend of making biorecognition elements based on microbial whole cells is their immobilization in sol gel matrices (Sakai et al., 1995; Chen et al., 2002). These elements are highly permeable for analyzed samples, have a good strength and stability, as well as low toxicity for immobilized microorganisms. However, fabrication of these films is a rather complex problem, because most sol gel formation methods are based on the temperature treatment of the reagent mixture.

\section{Standards used for calibration of BOD sensors}

The choice of the correct standard for calibration of a BOD biosensor is one of the key factors that determine the correlation between $\mathrm{BOD}_{\mathrm{bs}}$ and $\mathrm{BOD}_{5}$. The solution of a mixture of glucose and glutamic acid (GGA) at a total concentration of $300 \mathrm{mg} / \mathrm{dm}^{3}$ (glucose, $150 \mathrm{mg} / \mathrm{dm}^{3}$; glutamic acid, $150 \mathrm{mg} / \mathrm{dm}^{3}$ ), which corresponds to the $B D_{5}$ of $205 \mathrm{mg} / \mathrm{dm}^{3}$, is usually used. Although GGA is widely used as the standard for the classical method of BOD measurement (Testing Methods..., 1990; PNDF 14...., 1997; Standard Methods..., 1992), this mixture does not satisfy the conditions for the calibration of microbial BOD sensors. Firstly, GGA is unstable due to rapid microbial contamination; secondly, the rate of glutamic acid oxidation by microorganisms decreases in the presence of glucose, which does not in practice affect the 5-day analysis, but may have a strong effect on the result of an express analysis. Thirdly, GGA consists of only two readily oxidized components, and real waste waters are a complex mixture of components, predominantly with low oxidation rates, so GGA calibration may give unreliable results (Liu \& Mattiasson, 2002). 
Much attention at present is given to the development of calibration solutions - synthetic waste waters containing an approximate list of compounds, which are the main components of analyzed water samples (Liu et al. 2000; Sakaguchi et al., 2003; Jianbo et al., 2003; Thévenot et al., 2001; Kim \& Park, 2001; Melidis et al., 2008; Tanaka et al., 1994). The most widely used are synthetic waste waters recommended by the Organization for Economic Cooperation and Development (OECD), whose basic components are peptone, meat extract, urea and various inorganic salts (Organization for Economic Corporation and Development..., 1991). As compared with the GGA calibration, the calibration using the OECD standard makes it possible to increase significantly the correlation between the $\mathrm{BOD}_{\mathrm{bs}}$ and $\mathrm{BOD}_{5}($ Liu \& Mattiasson, 2002). A number of publications also describe the use of other standards for calibration of the BOD biosensor (Chee et al., 2000; Lehmann et al., 1999; Tanaka et al., 1994); however, those compositions can simulate the composition of only certain types of waste waters and are not universal.

\section{Characteristics of various types of BOD sensors}

The efficiency of a biosensor is determined by its analytical and metrological characteristics and operational parameters. They include the properties of the analytical signal (response value and time) in response to the addition of an analyzed substance, reversibility of the system after the analyte is removed, stability of the biosensor, the measurement technique, operational conditions and many others. Optimization of the biosensor system is an integrated problem, because often an improvement of one property leads to a deterioration of another.

To obtain quantitative information about the content of analyzed substances in a sample, it is necessary to know the calibration characteristics of the BOD biosensor, i.e., the dependence of the analytical signal on the concentration of the tested compound. The description of the calibration should indicate under which conditions it was obtained and for which calibration solution. The linear character of the dependence of BOD biosensor responses on the concentration within a certain interval is a measure of the possibility to determine the BOD in the analysis of waste waters with various concentrations of substrates. A broad linear interval is desirable for the measurements to be correct and reliable. The linear character of BOD biosensor characteristics in steady-state measurements is lower than when using the initial rate of change of the biosensor signal. Besides the calibration dependence proper, other quantitative characteristics are also used to compare the efficiency of biosensors: the sensitivity and the detection limit (Chen et al., 2002). The sensitivity coefficient is determined as the maximal value of the derivative of the response value with respect to the concentration. An important characteristic is the detection limit. In the case of amperometric biosensors, the following regularity can be observed. The sensitivity of the sensor can be increased by increasing the amount of biomaterial. Still, as a rule, this leads to a shift of the detection limit to the region of higher concentrations of the analyzed compound. Thus, the ratio of the detection limit to the sensitivity can be an objective characteristic of a biosensor.

The linear character and quantitative characteristics of the calibration dependence are related to the design of the transducer, type of sensor and concentration of cells in the recognition element. BOD sensors with a high density of cells in the biofilm are usually more 
sensitive but have a narrower linear interval. These parameters are also affected by the sensitivity of the sensor with respect to certain types of organic compounds. A BOD sensor may yield dissimilar linear characteristics when using different calibration solutions and samples with different compositions of organic substrates.

As the goal of developing BOD sensors is to set up a fast alternative analytical method, the analysis by means of biosensors should be no less accurate than by the traditional $\mathrm{BOD}_{5}$ method. The $\mathrm{BOD}_{5}$ is determined in the 5-day test by the GGA standard solution, for which the averaged value of $\mathrm{BOD}_{5}$ is $205 \mathrm{mg} / \mathrm{l}$, and the standard deviation is $30.5 \mathrm{mg} / \mathrm{l}$, which is about $15.4 \%$. The repeatability of biofilm-type BOD sensors varies within the limits of 10 $11 \%$ for a sensor based on one strain, and increases up to $15 \%$ for sensors based on a microbial association (Liu \& Mattiasson, 2002).

An important consumer quality of biosensors is analysis time, which sums up from the biosensor response time and bioreceptor element activity recovery time. The BOD sensor response time varies, first and foremost, depending on the measuring technique used. The sensor signal can be registered after 5-25 min in steady-state measurements and after 15-30 s in measurements of the initial rate. In steady-state measurements, the new steady-state setup time depends on the concentration of substrate in the sample and increases significantly in the analysis of samples with high concentrations of substrates. Usually the time required for the base line to be restored is greater than the signal development time, i.e., 15-60 min in the processing of the signal by the equilibrium method and $5-10 \mathrm{~min}$ in the processing by the kinetic method, respectively.

It should be noted that waste waters of some productions, e.g., cereal-processing enterprises (distilleries, breweries, starch plants) are characterized by a high content of organic impurities leading to the death of the surrounding natural ecosystems. A major problem is the utilization of liquid wastes. The first step in the utilization consists in the examination of wastes for the content of organic components. For such enterprises, it is not only difficult in practice, but also inexpedient to try to develop a universal BOD sensor. It is reasonable to design biosensors and choose respective microorganisms that would provide for the most efficient detection of BOD in accordance with the particular type of waste waters, i.e., to develop specialized BOD biosensors. Thus, to control the extent of purification of waste waters in a starch works, it was proposed to use in the BOD biosensor acetobacteria Gluconobacter oxydans that provide for a high sensitivity to alcohols and sugars (Jung et al., 1995; Arlyapov et al., 2008b); this enabled the development of an express method for controlling the BOD of the waste waters of that works. The problem of pollution of the environment with organic compounds is the most acute in distillery industry, in particular, with respect to the utilization of distiller's spent grains, the main production waste. A biosensor method for determining the general content of readily oxidized organic compounds in the wastes of such fermentation plants was developed (Arlyapov et al., 2008a; Reshetilov et al.,. 2008). The method of analysis using the developed biosensor has a high speed, high sensitivity and selectivity. The authors note that biosensors intended for the ecological control of food-production waste waters can be also used for monitoring the fermentation processes at these productions. This will make it possible to reduce expenses for the equipment and to increase the economic returns of the enterprise.

Some characteristics and parameters of various types of BOD biosensors described in the literature are given in Table 1. 


\begin{tabular}{|c|c|c|c|}
\hline Microorganisms, immobilization & Measurement conditions & Characteristics & Reference, year \\
\hline $\begin{array}{l}\text { Activated sludge preparation whose } \\
\text { cells were killed by heating at } 300^{\circ} \mathrm{C} \text { for } \\
1.75 \mathrm{~min}\end{array}$ & GGA & & Tan \& Lim, 2005 \\
\hline $\begin{array}{l}\text { Association of microorganisms } \\
\text { immobilized on a nylon membrane }\end{array}$ & $\begin{array}{l}\text { GGA, analysis of waste water } \\
\text { samples }\end{array}$ & $\begin{array}{l}\text { rResponse time } 90 \text { min, stability for } 400 \\
\text { measurement cycles, storage at } 4^{\circ} \mathrm{C} \text {, lower } \\
\text { detection limit } 1 \mathrm{mg} \mathrm{O}_{2} \mathrm{I}^{-1} \text {, correlation between } \\
\mathrm{BOD}_{\mathrm{bs}} \text { and } \mathrm{BOD}_{5} \text { (deviation } 10 \% \text { ), convergence } \\
3.39-4.45 \% \text {, reproducibility } 1.85-2.25 \%\end{array}$ & Dhall et al., 2008 \\
\hline $\begin{array}{l}\text { Gluconobacter oxydans cells } \\
\text { immobilized by adsorption on a } \\
\text { Whatman GF/A glass fibre filter }\end{array}$ & $\begin{array}{l}\text { GGA, analysis of food- } \\
\text { production waste waters }\end{array}$ & $\begin{array}{l}\text { Stable operation time } 12 \text { days, sensitivity } 0.28 \\
\mathrm{nA} \times \mathrm{dm}^{3} / \mathrm{min} \times \mathrm{mg} \text {, duration of measurement } \\
7-10 \mathrm{~min} \text {, linear range of } \mathrm{BOD}_{5} \text { biosensor } \\
\text { response dependence } 2.0-20.3 \mathrm{mg} / \mathrm{dm}^{3}\end{array}$ & $\begin{array}{l}\text { Arlyapov } \\
\text { et al., 2008b }\end{array}$ \\
\hline Microbial association & $\begin{array}{l}\text { Synthetic waste waters } \\
(\mathrm{OECD}) \text {, waste waters of a } \\
\text { rubber-treatment plant }\end{array}$ & $\begin{array}{l}\text { Biosensor response time } 10-15 \mathrm{~min} \text {, difference } \\
\text { between the values of the standard method } \\
\text { less than } 10 \%\end{array}$ & $\begin{array}{l}\text { Kumlanghan } \\
\text { et al., } 2008\end{array}$ \\
\hline $\begin{array}{l}\text { Saccharomyces cerevisiae cells, } \\
\text { encapsulation in calcium alginate }\end{array}$ & $\begin{array}{l}\text { GGA, analysis of waste water } \\
\text { samples }\end{array}$ & $\begin{array}{l}\text { rFor a } 20 \text {-ppm calibration solution the } \\
\text { correspondence between } \mathrm{BOD}_{\mathrm{bs}} \text { and } \mathrm{BOD}_{5} \text { is } r \\
=0.95(n=6)\end{array}$ & Seo et al., 2009 \\
\hline $\begin{array}{l}\text { Debaryomyces hansenii cells } \\
\text { immobilized by adsorption }\end{array}$ & $\begin{array}{l}\mathrm{GGA} \text {, analysis of communal } \\
\text { and biotechnological waste } \\
\text { waters }\end{array}$ & $\begin{array}{l}\text { Stable operation time "/>30 days, duration of } \\
\text { single measurement } 10-17 \mathrm{~min} \text {, linear range } \\
\text { of } \mathrm{BOD}_{5} \text { biosensor response dependence } 2.2- \\
177 \mathrm{mg} / \mathrm{dm}^{3}\end{array}$ & $\begin{array}{l}\text { Arlyapov } \\
\text { et al., } 2012\end{array}$ \\
\hline $\begin{array}{l}\text { Microbial associations of } \\
\text { Debaryomyces hansenii, Pichia angusta } \\
\text { and Arxula adeninovorans }\end{array}$ & $\begin{array}{l}\text { GGA, samples of } \\
\text { fermentation mass and } \\
\text { waste waters of waste-water } \\
\text { treatment facilities }\end{array}$ & $\begin{array}{l}\text { Stable operation time } 31 \text { days, duration of } \\
\text { single measurement } 10-15 \mathrm{~min} \text {, linear range } \\
\text { rof } \mathrm{BOD}_{5} \text { biosensor response dependence } 1-93 \\
\mathrm{mg} / \mathrm{dm}^{3}\end{array}$ & $\begin{array}{l}\text { Kamanin } \\
\text { et al., } 2012\end{array}$ \\
\hline $\begin{array}{l}\text { Strain Aeromonas hydrophila P69.1 } \\
\text { immobilized using a semipermeable } \\
\text { membrane }\end{array}$ & $\begin{array}{l}\text { Synthetic waste waters } \\
(O E C D) \text {, waste waters from } \\
\text { meat-processing plants }\end{array}$ & $\begin{array}{l}\text { Linear range of } \mathrm{BOD}_{7} \text { biosensor response } \\
\text { dependence } 5-45 \mathrm{mg} / \mathrm{dm}^{3} \text {, biosensor lifetime } \\
110 \text { days, biosensor response time up to } 20 \\
\text { min }\end{array}$ & Raud et al., 2012 \\
\hline
\end{tabular}

\section{Mediator-type BOD biosensors}

Yeast Saccharomyces cerevisiae, a two- Analysis of sea water and mediator system with ferricyanide and river water samples lipophilic mediator menadione
Linear range within $1 \mu \mathrm{M}$ to $10 \mathrm{mM}$ concentration of hexacyanoferrate (II) (r

${ }^{2}=0.9995$, relative standard deviation $=1.3 \%$ ).

For 14 days under storage conditions at $4^{\circ} \mathrm{C}$,

decrease of sensor response $93 \%$
Nakamura et al., 2007b 


\begin{tabular}{|c|c|c|c|}
\hline Microorganisms, immobilization & Measurement conditions & Characteristics & Reference, year \\
\hline $\begin{array}{l}\text { Glass-carbon electrode modified by } \\
\text { ferricyanide in ion-exchange } \\
\text { polysiloxane }\end{array}$ & GGA, sea water samples & $\begin{array}{l}\text { Linear interval up to } 40 \mathrm{mg} \mathrm{O}_{2} \mathrm{I}^{-1}(r=0.994) \text {, } \\
\text { convergence }<3.8 \% \text {, reproducibility }<7.7 \% \text {, } \\
\text { correspondence between } \mathrm{BOD}_{\text {bs }} \text { and } \mathrm{BOD}_{5}(r= \\
0.988)\end{array}$ & Chen et al., 2008 \\
\hline $\begin{array}{l}\text { Bacteria Gluconobacter oxydans in } \\
\text { graphite paste with mediator ferrocene }\end{array}$ & $\begin{array}{l}\text { GGA, analysis of food- } \\
\text { eproduction waste waters }\end{array}$ & $\begin{array}{l}\text { Stable operation time } 30 \text { days, sensitivity } 4 \\
\mathrm{nA} \times \mathrm{dm}^{3} / \mathrm{mg} \text {, duration of single measurement } \\
6-7.5 \mathrm{~min} \text {, linear range of } \mathrm{BOD}_{5} \text { biosensor } \\
\text { response dependence } 34-680 \mathrm{mg} / \mathrm{dm}^{3}\end{array}$ & $\begin{array}{l}\text { Arlyapov } \\
\text { et al., 2008a }\end{array}$ \\
\hline $\begin{array}{l}\text { Klebsiella pneumoniae cells, } \\
\text { ferricyanide mediator }\end{array}$ & $\begin{array}{l}\text { GGA; synthetic waste waters } \\
(\mathrm{OECD}) \text {, municipal waste } \\
\text { waters }\end{array}$ & $\begin{array}{l}\text { Linear range of } \mathrm{BOD}_{5} \text { biosensor response } \\
\text { dependence } 30-500 \mathrm{mg} / \mathrm{l} \text { or } 30-200 \mathrm{mg} / \mathrm{l} \text {, } \\
\text { using GGA and synthetic waste waters, } \\
\text { respectively }\end{array}$ & $\begin{array}{l}\text { Bonetto } \\
\text { et al., } 2011\end{array}$ \\
\hline $\begin{array}{l}\text { Escherichia coli cells immobilized in } \\
\text { PVC-polyvinyl pyridine copolymer; } \\
\text { mediator, neutral red }\end{array}$ & $\begin{array}{l}\text { GGA; synthetic waste waters } \\
(\mathrm{OECD}) \text {; urea and real waste } \\
\text { waters }\end{array}$ & & Liu et al., 2012 \\
\hline
\end{tabular}

\section{Optical BOD biosensors}

\begin{tabular}{|c|c|c|c|}
\hline $\begin{array}{l}\text { Bacillus subtilis cells im-mobilized into } \\
\text { composite sol gel of quartz and } \\
\text { polyvinyl alcohol; oxygen-sensitive film } \\
\text { from tris(4,7-diphenyl-1.10- } \\
\text { phenanthroline)-ruthenium(II) }\end{array}$ & GGA & & $\begin{array}{l}\text { Kwok } \\
\text { et al., } 2005\end{array}$ \\
\hline $\begin{array}{l}\text { Microorganisms Bacillus licheniformis, } \\
\text { Dietzia maris and Marinobacter marinus } \\
\text { from sea water, immobilized in } \\
\text { polyvinyl alcohol. Sensitive film from } \\
\text { organically modified silicate film, with } \\
\text { em- bedded ruthenium com-plex } \\
\text { sensitive to oxygen }\end{array}$ & GGA; sea water samples & $\begin{array}{l}\text { Stable operation time up to } 10 \text { months; with } \\
\text { GGA as a standard, the correlation coefficient } \\
\left(R^{2}\right) \text { within the range of } 0.3-40 \mathrm{mg} / \mathrm{B} \text { BOD was } \\
0.985 \text {; reproducibility, } \pm 2.3 \%\end{array}$ & $\begin{array}{l}\text { Lin et al } \\
\text { 2006; } \\
\text { Jiang et al., } 2006\end{array}$ \\
\hline \multicolumn{4}{|l|}{ BFC-based BOD biosensors } \\
\hline & $\begin{array}{l}\text { Real-time monitoring of } \\
\text { waste waters }\end{array}$ & $\begin{array}{l}\text { Stable current in } 60 \text { min after introduction of } \\
\text { samples at various concentrations into a } \\
\text { biofuel cell; reproducibility } 10 \% \text { in the } \\
\text { determination of BOD at a concentration of } \\
100 \mathrm{mg} / \mathrm{l}\end{array}$ & $\begin{array}{l}\text { Chang et al., 2004, } \\
2005\end{array}$ \\
\hline & $\begin{array}{l}\text { Synthetic and real waste } \\
\text { waters }\end{array}$ & $\begin{array}{l}\text { Linear dependence on BOD up to } 350 \mathrm{mg} / \mathrm{ml} \text {; } \\
\text { stable operation time, } 7 \text { months }\end{array}$ & $\begin{array}{l}\text { Di Lorenzo } \\
\text { et al., } 2009\end{array}$ \\
\hline
\end{tabular}




\begin{tabular}{|c|c|c|c|}
\hline Microorganisms, immobilization & Measurement conditions & Characteristics & Reference, year \\
\hline \multicolumn{4}{|c|}{ BOD biosensors based on other registration methods } \\
\hline $\begin{array}{l}\text { Measurement of the concentration of } \\
\mathrm{CO}_{2} \text {, produced by the degradation of } \\
\text { waste waters' carbon component by } \\
\text { microorganisms. Control of } \mathrm{CO}_{2} \text { using } \\
\text { an infrared spectrometer }\end{array}$ & $\begin{array}{l}\text { Real-time determination of } \\
\text { the BOD of waste water } \\
\text { treatment facilities }\end{array}$ & & $\begin{array}{l}\text { Vaiopoulou et al., } \\
2005\end{array}$ \\
\hline $\begin{array}{l}\text { Amperometric bioelectric "language" } \\
\text { in the group cell using mathematical } \\
\text { data processing methods. Modification } \\
\text { of electrodes by tyrosinase, horseradish } \\
\text { peroxidase, acetylcholin-esterase and } \\
\text { butyrylcholinesterase. }\end{array}$ & Samples of waste waters & & $\begin{array}{l}\text { Tønning } \\
\text { et al., } 2005\end{array}$ \\
\hline $\begin{array}{l}\text { Activated sludge, } \mathrm{pH} \text {-transducer. } \\
\text { Determination of } \mathrm{CO}_{2} \text { under aerobic } \\
\text { conditions and of } \mathrm{NaOH} \text { under } \\
\text { anaerobic conditions }\end{array}$ & $\begin{array}{l}\text { Monitoring of the extent of } \\
\text { pollution with organic } \\
\text { compounds and of toxicity }\end{array}$ & & Melidis et al., 2008 \\
\hline $\begin{array}{l}\text { Saccharomyces cere-visiae, the } \\
\text { colorimetric method in the presence of } \\
\text { 2,6-dichlorophenol-indophenol }\end{array}$ & GGA; river water samples & $\begin{array}{l}\text { Linear interval } 1.1-22 \mathrm{mg} \\
\mathrm{O}_{2} \mathrm{~L}^{-1}(r=0.988, n=3) \text {, storage } 36 \text { days }\end{array}$ & $\begin{array}{l}\text { Nakamura et al., } \\
\text { 2007a }\end{array}$ \\
\hline
\end{tabular}

Table 1. Characteristics and parameters of BOD sensors

\section{Commercial BOD biosensors}

Most biosensor designs described in the literature have remained breadboard models. To date, only several models of BOD biosensors are available commercially. The first commercial model of biosensor for the BOD analysis was put on the market by Nisshin Electric Co. Ltd in 1983. Later, several commercial BOD biosensor analysers were produced by other Japanese (Central Kagaku Corp.) and European (Dr. Lange GmbH, Aucoteam GmbH, Prufgeratewerk Medingen $\mathrm{GmbH}$ ) companies. The first commercial BOD sensors were Clark's oxygen electrode-based biosensors and, as a rule, made use of activated sludge as receptor element substrate (Liu \& Mattiasson, 2002).

The method of BOD analysis using biosensors was included into the Japanese Industrial Standard in 1990 (JIS K3602). Several models of BOD biosensors are sold on the market at present: QuickBOD $\alpha 1000$, BOD-3300, HABS-2000 (all by Central Kagaku Corp., Japan) (http://www.aqua-ckc.jp/product2/bod.html\#top). The model BOD-3300 enables the BOD determination within the range of $0-500 \mathrm{mg} / \mathrm{l}$ in 30-60 min and costs about 80 thousand US dollars. The weight of the analyzer is $\sim 210 \mathrm{~kg}$. QuickBOD $\alpha 1000$ is a more advanced device 
developed by Japanese engineers and makes it possible to determine the BOD within the range of $2-50 \mathrm{mg} / \mathrm{l}$ in $60 \mathrm{~min}$; the weight of the device is $16 \mathrm{~kg}$ and its cost is 30 thousand US dollars. It should be noted that this analyzer, in contrast with its many precursors is based on the use of one culture (T. cutaneum).

\section{Conclusion}

Thus, the determination of the BOD by means of biosensors is a rather advanced trend of analytical biotechnology. However, BOD biosensors have a number of limitations that impede their use, so it is topical to conduct own Russian research and to perform works establishing the basis for commercial production of BOD biosensors. Biosensor BOD analyzers are robust, simple and cheap analytical tools that can be successfully used for controlling aqueous ecosystems along with the traditional BOD determination methods.

\section{Author details}

\section{A. Reshetilov ${ }^{1}$, V. Arlyapov ${ }^{2}$, V. Alferov ${ }^{2}$ and T. Reshetilova ${ }^{1}$}

1 Federal State Budgetary Institution of Science, G.K. Skryabin Institute of Biochemistry and Physiology of Microorganisms, Russian Academy of Sciences, 5 Pr. Nauki, Pushchino, Moscow Region, Russia

2 Federal State Budgetary Educational Institution of Higher Professional Education, Tula State University, Tula, Russia

\section{References}

[1] Arlyapov, V. A., Chigrinova, E., Yu, , Ponamoreva, O. N., \& Reshetilov, A. N. (2008a). Express detection of BOD in wastewaters of starch-processing industry. Starch Science and Technology, Ed. G.E. Zaikov. New York: Nova Science Publishers, 978-1-60456-950-6, 161-175.

[2] Arlyapov, V., Kamanin, S., Ponamoreva, O., \& Reshetilov, A. (2012). Biosensor analyzer for BOD index express control on the basis of the yeast microorganisms Candida maltosa, Candida blankii, and Debaryomyces hansenii. Enzyme Microb. Technol., Iss. 4-5, 0141-0229, 50, 215-220.

[3] Arlyapov, V. A., Ponamoreva, O. N., Alferov, V. A., Rogova, T. V., Blokhin, I. V., Chepkova, I. F., \& Reshetilov, A. N. (2008b). Microbial biosensors for express detection of BOD in wastewaters of food enterprises. Voda: Khim. Ekol., in Russian), 2072-8158(3), 20-22. 
[4] Baeumner, A. J. (2003). Biosensors for environmental pollutants and food contaminants.Anal. Bioanal. Chem., 1618-2642, 377, 434-445.

[5] Bourgeois, W., Burgess, J. E., \& Stuetz, R. M. (2001). On-line monitoring of wastewater quality: a review. J. Chem. Techn. Biotechn., 0268-2575, 76, 337-348.

[6] Bonetto, M. C., Sacco, N. J., Ohlsson, A. H., \& Cortón, E. (2011). Assessing the effect of oxygen and microbial inhibitors to optimize ferricyanide-mediated BOD assay.Talanta., Iss. 1, 0039-9140, 85, 455-462.

[7] Chan, C., Lehmann, M., Chan, K., Chan, P., Chan, C., Gruendig, B., Kunze, G., \& Renneberg, R. (2000). Designing an amperometric thick-film microbial BOD sensor. Biosens. Bioelectron., 0956-5663, 15(7), 343-353.

[8] Chang, I. S., Jang, J. K., Gil, G. C., Kim, M., Kim, H. J., Cho, B. W., \& Kim, B. H. (2004). Continuous determination of biochemical oxygen demand using microbial fuel cell type biosensor. Biosens. Bioelectron., 0956-5663, 19(6), 607-613.

[9] Chang, I. S., Moon, H., Jang, J. K., \& Kim, B. H. (2005). Fluorescence and bioluminescence of bacterial luciferase intermediates. Biosens. Bioelectron., 0956-5663, 20(9), 1856-1859.

[10] Chee, G., \& , J. (2011). Biosensor for the determination of biochemical oxygen demand in rivers. Environmental Biosensors, Ed. Vernon Somerset, InTech Publishers, 978-9-53307-486-3, 257-276.

[11] Chee, G., , J., Nomura, Y., Ikebukuro, K., \& Karube, I. (2000). Optical fiber biosensor for the determination of low biochemical oxygen demand. Biosens. Bioelectron., 0956-5663, 15(7-8), 371-376.

[12] Chen, D., Cao, Y., Liu, B., \& Kong, J. (2002). A BOD biosensor based on a microorganism immobilized on an $\mathrm{Al}_{2} \mathrm{O}_{3}$ sol-gel matrix. Anal. Bioanal. Chem., 1618-2642, 372, 737-739.

[13] Chen, H., Ye, T., Qiu, B., Chen, G., \& Chen, X. (2008). A novel approach based on ferricyanide-mediator immobilized in an ion-exchangeable biosensing film for the determination of biochemical oxygen demand. Anal. Chim. Acta, 0003-2670, 612(1), 75-82.

[14] Deng, H., Chen, Zh., \& Zhao, F. (2012). Energy from plants and microorganisms: progress in plant-microbial fuel cells. ChemSusChem, 5, 1006-1011, 1864-5631.

[15] Dhall, P., Kumar, A., Joshi, A., Saxsena, T. K., Manoharan, A., Makhijani, S. D., \& Kumar, R. (2008). Quick and reliable estimation of bod load of beverage industrial wastewater by developing bod biosensor. Sens. Act.B, 0925-4005, 133(2), 478-483.

[16] Di Lorenzo, M., Curtis, T. P., Head, I. M., \& Scott, K. (2009). A single-chamber microbial fuel cell as a biosensor for wastewaters. Water Res., Iss. 13, 0043-1354, 43, 3145-3154. 
[17] D'Souza, S. F. (2001). Microbial biosensors. Biosens. Bioelectron.,0956-5663, 16, 337-353.

[18] Du, Zh., Li, H., \& Gu, T. (2007). A state of the art review on microbial fuel cells: a promising technology for wastewater treatment and bioenergy. Biotechnol. Adv., 0734-9750, 25, 464-482.

[19] Farré, M., \& Barceló, D. (2001). Characterization of wastewater toxicity by means of a whole-cell bacterial biosensor, using Pseudomonas putida, in conjunction with chemical analysis. Fresenius J. Anal. Chem., 0937-0633(371), 467-473.

[20] Guo, G., , M., Xin, L., , L., Wang, X., , D., Zhao, Y., \& Chen, X. (2008). Study on the fluorescence characteristics of BOD sensing films immobilizing different limnetic microorganism. s. Guang Pu Xue Yu Guang Pu Fen Xi / Spectroscopy and Spectral Analysis, 1000-0593, 28, 2134-2138.

[21] Heim, S., Schnieder, I., Binz, D., Vogel, A., \& Bilitewski, U. (1999). Development of an automated microbial sensor system. Biosens. Bioelectron., 0956-5663, 14, 187-193.

[22] Hikuma, M., Suzuki, H., Yasuda, T., Karube, I., \& Suzuki, S. (1979). Amperometric estimation of BOD by using living immobilized yeast. Eur. J. Appl. Microbiol. Biotechnol., 0171-1741, 8, 289-297.

[23] Hyun, C., , K., Tamiya, E., Takeuchi, T., \& Karube, I. (1993). A novel BOD sensor based on bacterial luminescence. Biotechnol. Bioeng., 0006-3592, 41, 1107-1118.

[24] Iranpour, R., \& Zermeno, M. (2008). Online biochemical oxygen demand monitoring for wastewater process control- full-scale studies at Los Angeles Glendale wastewater plant, California. Water Environ. Res., 1061-4303, 80(4), 24-29.

[25] Jianbo, J., Tang, M., Chen, X., Qi, L., \& Dong, S. (2003). Co-immobilized microbial biosensor for BOD estimation based on sol-gel derived composite material. Biosens. Bioelectron., 0956-5663, 18(8), 1023-1029.

[26] Jiang, Y., Xiao, L., , L., Zhao, L., Chen, X., Wang, X., Wong, K., \& , Y. (2006). Optical biosensor for the determination of BOD in seawater. Talanta, 0039-9140, 70(1), 97-103.

[27] Jung, J., Sofer, S., \& Lakhwala, F. (1995). Towards an on-line biochemical oxygen demand analyser. Biotechnol. Tech., 0095-1208X, 9(4), 289-294.

[28] Kamanin, S. S., Arlyapov, V. A., Ponamoreva, O. N., Alferov, V. A., \& Reshetilov, A. N. (2012). BOD-biosensor based on yeast strains. Voda: Khim. Ekol., in Russian), 2072-8158(3), 74-81.

[29] Karube, I., \& Yokoyama, K. (1993). Microbial sensors and micro-biosensors. NATO ASI Ser. E, 0016-8132X, 252, 281-288.

[30] Karube, I., Matsunaga, T., Tsuru, S., \& Suzuki, S. (1977a). Biochemical fuel cell utilizing immobilized cells of clostridium butyricum. Biotechnol. Bioeng., 0006-3592, 19, 1727-1760. 
[31] Karube, I., Mitsuda, S., Matsunaga, T., \& Suzuki, S. (1977b). Microbial electrode BOD sensors. Biotechnol. Bioeng., 0006-3592, 19(10), 1535-1547.

[32] Kim, B. H., Chang, I. S., Gil, G. C., Park, H. S., \& Kim, H. J. (2003a). Novel bod (biological oxygen demand) sensor using mediator-less microbial fuel cell. Biotechnol. Lett., 0141-5492, 25, 541-545.

[33] Kim, M., Youn, S. M., Shin, S. H., Jang, J. G., Han, S. H., Hyun, M. S., Gaddb, G. M., \& Kim, H. J. (2003b). Practical field application of a novel BOD monitoring system. J. Environ. Monit., 1464-0325, 2(5), 640-643.

[34] Kim, M., , N., Park, K., \& , H. (2001). Klebsiella BOD sensor. Sens. Act.B, 0925-4005, $80,9-14$.

[35] Kumlanghan, A., Kanatharana, P., Asawatreratanakul, P., Mattiasson, B., \& Thavarungkul, P. (2008). Microbial BOD sensor for monitoring treatment of wastewater from a rubber latex industry. Enzyme Microb. Technol., Iss. 6, 0141-0229, 42, 483-491.

[36] Kwok, N., , Y., Dong, S., Lo, W., Wong, K., \& , Y. (2005). An optical biosensor for multi-sample determination of biochemical oxygen demand (BOD). Sens. Act.B, 0925-4005, 110(2), 289-298.

[37] Lehmann, M., Chan, C., Lo, A., Lung, M., Tag, K., Kunze, G., Riedel, K., Gruendig, B., \& Renneberg, R. (1999). Measurement of biodegradable substances using the salt-tolerant yeast Arxula adeninivorans for a microbial sensor immobilized with poly(carbamoyl) sulfonate (PVS): Part II: application of the novel biosensor to real samples from coastal and island regions. Biosens. Bioelectron., 0956-5663, 14, 295-302.

[38] Lei, Y., Chen, W., \& Mulchandani, A. (2006). Microbial biosensors (review). Anal. Chim. Acta, 0003-2670, 568, 200-210.

[39] Lin, L., Xiao, L., , L., Huang, S., Zhao, L., Cui, J., , S., Wang, X., , H., \& Chen, X. N. (2006). Novel BOD optical fiber biosensor based on co-immobilized microorganisms in ormosils matrix. Biosens. Bioelectron., 0956-5663, 21(9), 1703-1709.

[40] Liu, J., Bjornsson, L., \& Mattiasson, B. (2000). Immobilised activated sludge based biosensor for biochemical oxygen demand measurement. Biosens. Bioelectron., 0956-5663, 14(12), 883-993.

[41] Liu, J., \& Mattiasson, B. (2002). Microbial BOD sensors for wastewater analysis. Water Res., 0043-1354, 36, 3786-3802.

[42] Liu, L., Zhang, S., Xing, L., Zhao, H., \& Dong, S. (2012). A co-immobilized mediator and microorganism mediated method combined pretreatment by $\mathrm{TiO}_{2}$ nanotubes used for BOD measurement. Talanta,. 93, 314-319, 0039-9140.

[43] Liua, L., Shanga, L., Liua, C., Liua, C., Zhanga, B., \& Dong, S. (2010). A new mediator method for bod measurement under non-deaerated condition. Talanta, 0039-9140, 81(4-5), 1170-1175. 
[44] Mattiasson, B., Larsson, P. O., \& Mosbach, K. (1977). The microbe thermistor. Nature, 268, 519-520, 0028-0836.

[45] Melidis, P., Vaiopoulou, E., \& Aivasidis, A. (2008). Development and implementation of microbial sensors for efficient process control in wastewater treatment plants. Bioprocess Biosyst. Eng., 1615-7591, 31(3), 277-352.

[46] Moon, H., Chang, I. S., Kang, K. H., Jang, J. K., \& Kim, B. H. (2004). Improving the dynamic response of a mediator-less microbial fuel cell as a biochemical oxygen demand (BOD) sensor. Biotechnol. Lett., 0141-5492, 26(22), 1717-1738.

[47] Nakamura, H., Kobayashi, S., Hirata, Y., Suzuki, K., Mogi, Y., \& Karube, I. 2007a). A spectrophotometric biochemical oxygen demand determination method using 2,6-dichlorophenolindophenol as the redox color indicator and the eukaryote Saccharomyces cerevi. siae. Anal. Biochem., 0003-2697, 369(2), 168-174.

[48] Nakamura, H., Suzuki, K., Ishikuro, H., Kinoshita, S., Koizumi, R., Okuma, S., Gotoh, M., \& Karube, I. (2007b). A new BOD estimation method employing a double-mediator system by ferricyanide and menadione using the eukaryote Saccharomyces cerevisiae. Talanta, 72(1), 210-216, 0039-9140.

[49] Organization for Economic Cooperation and Development (OECD), OECD Guidel.Testing Chem., (1991).

[50] Pang, H. L., Kwok, N. Y., Chan, P. H., Yeung, C. H., Lo, W., \& Wong, K. Y. (2007). High-throughput determination of biochemical oxygen demand (BOD) by a microplate-based biosensor. Environ. Sci. Technol., 0001-3936X, 4(11), 4038-4082.

[51] Pasco, N., Baronian, K., Jeffries, C., Webber, J., \& Haya, J. (2004). Micredox®- development of a ferricyanide-mediated rapid biochemical oxygen demand method using an immobilised proteus vulgaris biocomponent.Biosens. Bioelectron., 0956-5663, 20, 524-532.

[52] , P. N. D. F. 1., 1:2:3:, , \& 123-9, . The method of measuring the biochemical oxygen demand after $\mathrm{n}$ days of incubation $\left(\mathrm{BOD}_{\text {complete }}\right)$ in surface fresh, subsurface (ground), drinking, waste and purified waste waters. Moscow, (1997). pp. (in Russian)

[53] Ponomareva, O. N., Arlyapov, V. A., Alferov, V. A., \& Reshetilov, A. N. (2011). Microbial biosensors for detection of biological oxygen demand (review). Appl. Biochem. Microbiol., 0003-6838, 47, 1-11.

[54] Praet, E., Reuter, V., Gaillard, T., Vasel, J., \& (1995, L. (1995). Bioreactors and biomembranes for biochemical oxygen demand estimation. Trends Anal Chem., 0165-9936, 14(7), 371-378.

[55] Qian, Z., \& Tan, T. C. (1999). BOD measurement in the presence of heavy metal ions using a thermally-killed-Bacillus subtilis biosensor. Water Res., 0043-1354, 33(13), 2923-2928.

[56] Raud, M., Tenno, T., Jõgi, E., \& Kikas, T. (2012). Comparative study of semi-specific Aeromonas hydrophila and universal Pseudomonas fluorescens biosensors for BOD 
measurements in meat industry wastewaters. Enzyme Microb. Technol., Iss. 4-5, 2012, 0141-0229, 50, 221-226.

[57] Reshetilov, A. N., Alferov, V. A., Ledenev, V. P., \& Sergeyev, V. I. (2008). A novel method of rapid test in alcohol production. Likerovodochn. Proizv. Vinodel., Iss. 99, in Russian), 3, 20-22.

[58] Rodriguez-Mozaz, S., de Alda, M. J. L., \& Barcelo, D. (2006). Biosensors as useful tools for environmental analysis and monitoring. Anal. Bioanal. Chem., 1618-2642, 386(4), 1025-1041.

[59] Sakaguchi, T., Kitagawa, K., Ando, T., Murakami, Y., Morita, Y., Yamamura, A., Yokoyama, K., \& Tamiya, E. (2003). A rapid BOD sensing system using luminescent recombinants of Escherichia coli.Biosens. Bioelectron., 0956-5663, 19(2), 115-121.

[60] Sakaguchi, T., Morioka, Y., Yamasaki, M., Iwanaga, J., Beppu, K., Maeda, H., \& Morita, Y. (2007). Rapid and onsite BOD sensing system using luminous bacterial cells-immobilized chip. Biosens. Bioelectron., 0956-5663, 22(7), 1345-1350.

[61] Sakai, Y., Abe, N., Takeuchi, S., \& Takahashi, F. (1995). BOD sensor using magnetic activated sludge. J. Ferment. Bioeng., 0092-2338X, 80(3), 300-303.

[62] Seo, K. S., Choo, K. H., Chang, H. N., \& Park, J. K. (2009). A flow injection analysis system with encapsulated high-density Saccharomyces cerevisiae cells for rapid determination of biochemical oxygen demand. Appl. Microbiol. Biotechnol., 0175-7598, 83(2), 217-223.

[63] Sohn, M., , J., Lee, J., , W., Chung, C., Ihn, G., , S., \& Hong, D. (1995). Rapid estimation of biochemical oxygen demand using a microbial multi-staged bioreactor. Anal. Chim. Acta, 0003-2670, 313(3), 221-228.

[64] Spanjers, H., Vanrolleghem, P., Olsson, G., \& Dold, P. (1996). Respirometry in control of the activated sludge process. Water Sci. Technol., Iss 3-4, 0273-1223, 34, 117-143.

[65] Spanjers, H., Olsson, G., \& Klapwijk, A. (1993). Determining influent short-term biochemical oxygen demand by combined respirometry and estimation. Water Sci. Technol., Iss. 11-12, 0273-1223, 28, 401-415.

[66] Spanjers, H., \& Klapwijk, A. (1991). Continuous estimation of short term oxygen demand from respiration measurements.Water Sci. Technol., Iss. 7, 0273-1223, 24, 29-32.

[67] Suriyawattanakul, L., Surareungchai, W., Sritongkam, P., Tanticharoen, M., \& Kirtikara, K. (2002). The use of co-immobilization of Trichosporon cutaneum and Bacillus licheniformis for a BOD sensor. Appl. Microbiol. Biotechnol., 0175-7598, 59(1), 40-44.

[68] Standard Methods for the Examination of Water and Wastewater(1992). Washington: Amer. Publ. Health Association, , 5.

[69] Tag, K., Lehmann, M., Chan, C., Renneberg, R., Riedel, K., \& Kunze, G. (2000). Measurement of biodegradable substances with a mycelia-sensor based on the salt tolerant yeast Arxula adeninivorans LS3. Sens. Act. B, 0925-4005, 67, 142-148. 
[70] Tan, T. C., Li, F., Neoh, K. G., \& (1993, . (1993). Measurement of BOD by initial rate of response of a microbial sensor. Sens. Act.B, 0925-4005(10), 137-142.

[71] Tan, T. C., \& Lim, E. W. C. (2005). Thermally killed cells of complex microbial culture for biosensor measurement of BOD of wastewater. Sens. Act. B, 0925-4005, 107(2), 546-551.

[72] Tanaka, H., Nakamura, E., Minamiyama, Y., \& Toyoda, T. (1994). BOD biosensor for secondary effluent from wastewater treatment plants. Water Sci. Technol., 0273-1223, 30(4), 215-227.

[73] Thévenot, R. D., Toth, K., Durst, A. D., \& Wilson, G. S. (2001). Electrochemical biosensors: recommended definitions and classification. Biosens. Bioelectron., 0956-5663, $16,121-131$.

[74] Testing Methods for Industrial Waste Water, JIS K3602, Japanese Industrial Standard Committee, Tokyo, 1990

[75] Tkac, J., Vostiar, I., Gorton, L., Gemeiner, P., \& Sturdik, E. (2003). Application to the analysis of ethanol during fermentation. Biosens. Bioelectron., 0956-5663, 18(9), $1125-1134$.

[76] Tønning, E., Sapelnikova, S., Christensen, J., Carlsson, C., Winther-Nielsen, M., Dock, E., Solna, R., Skladal, P., Nørgaard, L., Ruzgas, T., \& Emnéus, J. (2005). Chemometric exploration of an amperometric biosensor array for fast determination of wastewater quality. Biosens. Bioelectron., 0956-5663, 21(4), 608-617.

[77] Trosok, S. P., Driscoll, B. T., \& Luong, J. H. T. (2001). Mediated microbial biosensor using a novel yeast strain for wastewater BOD measurement. Appl. Microbiol. Biotechnol., 0175-7598, 56(3-4), 550-554.

[78] Vaiopoulou, E., Melidis, P., Kampragou, E., \& Aivasidis, A. (2005). On-line load monitoring of wastewaters with a respirographic microbial sensor. Biosens. Bioelectron., 0956-5663, 21(2), 365-371.

[79] Walmsley, R. M., \& Keenan, P. (2000). The eukaryote alternative: advantages of using yeasts in place of bacteria in microbial biosensor development. Biotechnol. Bioprocess Eng., 1226-8372, 5(6), 387-394.

[80] Xu, X., \& Ying, Y. (2011). Microbial biosensors for environmental monitoring and food analysis (review). Food Rev. Int., 8755-9129, 27, 300-329.

[81] Yang, Z., Sasaki, S., Karube, I., \& Suzuki, H. (1997). Fabrication of oxygen electrode arrays and their incorporation into sensors for measuring biochemical oxygen demand. Anal. Chim. Acta, 0003-2670, 357(1-2), 41-50.

[82] Yang, Z., Suzuki, H., Sasaki, S., \& Karube, I. (1996). Disposable sensor for biochemical oxygen demand. Appl. Microbiol. Biotechnol., 0175-7598, 46(1), 10-14. 
[83] Yoshida, N., Hoashi, J., Morita, T., Mc Niven, S. J., Nakamura, H., \& Karube, I. (2001). Improvement of a mediator-type biochemical oxygen demand sensor for on-site measurement. J. Biotechnol., 0168-1656, 88(3), 269-275.

[84] Yoshida, N., Yano, K., Morita, T., Mc Niven, S. J., Nakamura, H., \& Karube, I. (2000). A mediator-type biosensor as a new approach to biochemical oxygen demand estimation. Analyst, 0003-2654, 125(12), 2280-2284. 
